\title{
RESEARCHING WOMEN IN LEGAL HISTORY: THE CASE OF MISS BEBB
}

\section{Rosemary Auchmuty}

The goal of this workshop was to think about how we write legal biography. Drawing on the research I undertook into the life of Gwyneth Bebb, ${ }^{1}$ who in 1913 challenged the Law Society of England and Wales for their refusal to admit women to the solicitors' profession, I focused on the range of sources one might use to explore the lives of women in law, about whom there might be a few public records but little else, and on the ways in which sources, even official ones, might be imaginatively used. I was keen to indicate the significance of asking questions that mattered, not simply to in order to recreate a life, but to demonstrate its full significance. My argument was not just that these sources and techniques are useful for adding colour and context to otherwise bare accounts but that they are necessary, because a focus on public achievements will miss significant aspects of a woman's life even, perhaps, its very essence.

\section{The starting-point: what are you trying to do?}

The first consideration is the source material. How can we find out the details of a life? There is a tendency among students these days to rely on websites, and a temptation for scholars, too, to take our 'facts' from these. Websites are not a bad starting-point - it's surprisingly rewarding what you can pick up from a quick Google search: there's a huge amount of interesting, often amateur, genealogy, history and criticism there - but they are also problematic. The same ideas, the same stories get repeated endlessly and we can easily fall into the trap of seeing this as corroboration. Often it isn't; it's the just the same, possibly mistaken, source being repeated again and again - as I found. The story of Miss Bebb's legal challenge to the Law Society has been re-told so often that I thought, writing my article, that I could skim over this bit - that a brief summary of what happened would do. In fact, although I called it 'a brief summary', the account ran to two pages because I thought what was in the public domain was so over-simplified. This meant that, before I even embarked on finding out about my subject's life beyond her eponymous legal action (my initial goal), I had to check the facts of the case itself and revise existing accounts of the campaign that led to it. Even the public records had been misrepresented, and that was before I even got to the private ones!

This brings us to the second consideration of the legal biographer, which is equally crucial. Without sources, you can't really say much that is authoritative about your subject; but, even with them, you won't produce anything worthwhile unless you ask the right questions of your sources. Many short biographical studies - articles, say, like the one I was writing - present the known facts of the subject's life but fail to consider the questions that might immediately occur to the reader. Questions like, What was it like to be in that situation? How would that event have affected that person? In the absence of any direct reference, many scholars are loathe to 'speculate' (as they see it); and critics can be scathing about assertions like 'she must have ...' or 'she would have ...'.

\footnotetext{
${ }^{1}$ Rosemary Auchmuty, 'Whatever happened to Miss Bebb? Bebb v The Law Society and women’s history' (2010) 31 Legal Studies, pp.199-230.
} 
So we have two problems: our 'facts' are not always true, as published accounts may be dodgy, and our conjectures may not be founded in 'fact' - so we end up with maybe two sentences: birth, death, and a few achievements in between that can be conclusively 'proved' to have happened.

How the biographer deals with these two considerations depends fundamentally on what their aims are in tackling this particular life. It's why one account can differ so greatly from another; it's why history is often described as a 'dialogue between the past and the present'; and it's why we train research students to come up with a research question. What do you want to find out? What is the issue for you? It isn't 'all I know about X' for a biography any more than it is for an answer to an exam or coursework question.

\section{Exploring the range of sources}

I became interested in Miss Bebb as a consequence of research I did on early women law students at Cambridge and Oxford. ${ }^{2}$ The starting-point for that research had been the four litigants in Bebb v The Law Society, on behalf of whom Miss Bebb brought her test case. But where the other three women's careers could be established with relative ease, Miss Bebb's life - apart from that brief appearance eluded record. This piqued my interest.

The former Women's Library in London, now re-located to the London School of Economics, holds the scrapbooks of two of her fellow-litigants, Nancy Nettlefold and Maud Ingram. ${ }^{3}$ A record not only of the celebrated case but of the entire campaign for women's entry into the profession, these collections of newspaper cuttings, invitations, programmes and transcripts are a wonderful resource, immediate and moving. With these records, I could bring my account up to the celebratory dinner where Miss Bebb (by now Mrs Thomson) proposed the toast to the Bar. But they, too, stopped in 1920.

I was fortunate to have a small grant for that research that paid for a research assistant, and even more fortunate that my research assistant, an old friend I had worked with on a quite different project, ${ }^{4}$ happened to be not only a professional genealogist but an Oxford graduate - indeed, an exstudent of St Hugh's, Miss Bebb's own college - and therefore had the insider knowledge into their systems and records that I lacked. It was she who turned up Miss Bebb's educational records and found her birth, marriage and death certificates (and those of her children) at St Catherine's House, as well as details of surviving relatives like Gordon Bebb QC, to whom we wrote.

These are the building blocks of biography and, in the case of the marriage and death certificates, provided the essential clues to Miss Bebb's fate. Indeed, her death certificate, with its very full description of the causes of death and later correction by another hand, in a sense created my argument of Miss Bebb as a woman trying to combine motherhood and a career. But taking such

\footnotetext{
${ }^{2}$ Rosemary Auchmuty, 'Early women law students at Cambridge and Oxford’ (2008) 29 Journal of Legal History 63-97.

${ }^{3}$ Later Mrs Crofts. She became a solicitor and wrote Women Under English Law (London: National Council of Women of Great Britain, 1925).

${ }^{4}$ Sue Sims and Hilary Clare eds. The Encyclopaedia of Girls’ School Stories (Aldershot: Ashgate, 2000.
} 
sources on their own, in the absence of amplifying diaries, letters or reminiscences, sets up a rather individualised narrative. Poor Miss Bebb, what bad luck, she died in childbirth. A personal tragedy.

Of course it wasn't just like that. She died because of a public failing: her medical care was poor. It was poor because there was no National Health Service then and, crucially, because maternal health was not a government priority. It was poor because, even though the condition she died from was known and doctors might have been able to save her, she chose to have her baby in a nursing home (as middle-class women did) rather than a public hospital. I found statistics in Jane Lewis's still unsurpassed account of women in England ${ }^{5}$ at this period comparing the maternal mortality rate in middle-class Chelsea and working-class Hackney; the survival rate was better in Hackney, precisely because public hospitals were staffed by honorary consultants who knew what they were doing; and I used these to extrapolate that the risk for middle-class women in childbirth, unlikely as it might seem, was actually higher than for their working-class sisters at this time. Thus Miss Bebb is not just one unlucky individual but, in this situation, on of many people against whom the scales were weighted in terms of both gender and class.

I use this example to illustrate the technique I used for filling out the bare details of Miss Bebb's life. With no personal records to turn to, I fell back on context. This is where asking the right questions intersects with finding useful sources. Throughout my account, I kept asking myself: What would it have been like for her? You can never really get inside your subject, and I certainly never felt that Gwyneth Bebb and I had much in common beyond our gender and our feminism. But I could still try to reconstruct her life in the context of the society in which she moved.

Many years ago I wrote a chapter in a book on lesbian history entitled 'By Their Friends We Shall Know Them'. ${ }^{6}$ It was a study of women's friendship networks in Lambeth, where I lived at the time, intended to demonstrate that if you could identify some lesbians and then studied who they socialised with (these were all women in public life so there were plenty of sources for their lives) you could formulate a pretty good idea of which other women were lesbians at the time, in the absence of other evidence. If one woman lived with another, but had previously lived with a different woman who now lived with ... that sort of thing. I used the same technique for Miss Bebb. If I couldn't find out anything first-hand about her, I would investigate her associates; and they might cast light on her own circumstances.

For her schooldays there was nothing; the school no longer exists. But an Oxford women's college at that time is a goldmine, because the colleges all have extensive archives. Not only that, but the women's colleges, like the men's, were populated by outstanding women, many of whom became prominent in public life and wrote memoirs or had biographies written about them. It was not difficult to find half a dozen accounts of life at the Oxbridge women's colleges in this period (there

\footnotetext{
${ }^{5}$ Jane Lewis, Women in England 1870-1950 (Brighton: Wheatsheaf, 1984) pp.117-8.

${ }^{6}$ Rosemary Auchmuty, 'By Their Friends We Shall Know Them: The lives and networks of some women in North Lambeth, 1880-1940', in Lesbian History Group ed. Not a Passing Phase: Reclaiming Lesbians in History 1840-1984 (London: The Women's Press, 1989) 77-98.
} 
was also an institutional history of St Hugh's itself, which did not mention Miss Bebb) and I used these to try to reconstruct atmosphere, customs and rituals. For her law studies, which were shared with the men students, there were biographies of legal scholars to draw on (Dicey, Holdsworth et al), as later there were biographies of the judges in the Bebb case and the leading politicians in Parliament (such as Lord Buckmaster and Lord Robert Cecil) who endorsed or opposed the various reforming Bills. The ODNB, with its helpful bibliographies, was a constant resource, for one entry led often to another. For instance, I discovered that Violet Markham, with whom Miss Bebb worked in the National Service for Women during the war, was a close friend of Jack Hills, ${ }^{7}$ the solicitor MP who introduced the 1913 Bill to open the solicitors' profession to women in the wake of the failed court case.

I am sure that these connexions are not accidental. Nor was it accidental that Miss Bebb went to work after finishing at Oxford with Clara Collet at the Board of Trade. It was not just that her legal talents would have been useful for the work, which included bringing prosecutions against employers of women in the sweated trades; I feel sure that Miss Bebb must have known Miss Collet, because Miss Collet had studied law herself (at University College) and was a friend of one of the first women law students at Cambridge (they were at school together, as I had discovered from my earlier research into early women law students). The feminist world was a small one; probably everyone knew, or knew of, everyone else. This is important because advances for women are so often presented as the result of individual effort or, worse, concessions from above with no feminist input whatsoever.

In attempting to reconstruct Miss Bebb's experiences as a student at an Oxford women's college I drew on another type of source often overlooked by historians: fiction. 'College novels' form a distinct literary sub-genre for both adults and young people, and those written for girls were at their most fashionable in the very years that Miss Bebb was at university. Elsewhere I have argued ${ }^{8}$ that, while of course one must treat fiction as critically as any other sources, the fact that it is 'not true' does not mean it can't be of assistance to the historian in capturing aspects such as shared assumptions, customs and the atmosphere of the time and place. The background for girls' college novels was in any case always carefully researched by professional writers like L.T. Meade (the most popular writers for girls of the period), or, in other cases, drawn from the writer's own experience of college life. ${ }^{9}$

\footnotetext{
${ }^{7}$ Jack Hills's entry in the ODNB does not mention his support of women's entry into the legal profession. It focuses instead on his contribution to fly-fishing!

8 'The Woman Law Student and the Girls' College Novel' (2007) 19 Canadian Journal of Women and the Law 37-72.

${ }^{9}$ See, for example, L.T. Meade, The Girls of Merton College (London: Hurst and Co: 1911); Mrs Sinclair Stevenson, Hilary: the Story of a College Girl (Oxford University Press, [1920]).
} 
Because Miss Bebb left no written records and no one else seems to have left any record of her, on only two occasions did I 'hear' her voice in spoken exchanges recorded in print: in the transcript of the Bebb trial in the Chancery Division and in a newspaper extract from her speech at the 1920 dinner. In both brief glimpses she comes across as tactically conventional - she says the right things - but in such a way as to indicate that she was fully aware of the irony of her situation, indeed of the situation of all competent, educated women who were excluded from civil rights and offices for no reason except their sex. But if it proved impossible to say much that was definitive about her as an individual, it was not impossible to write about her as a member of a community - of college students, of feminist campaigners, of middle-class wives and mothers. 


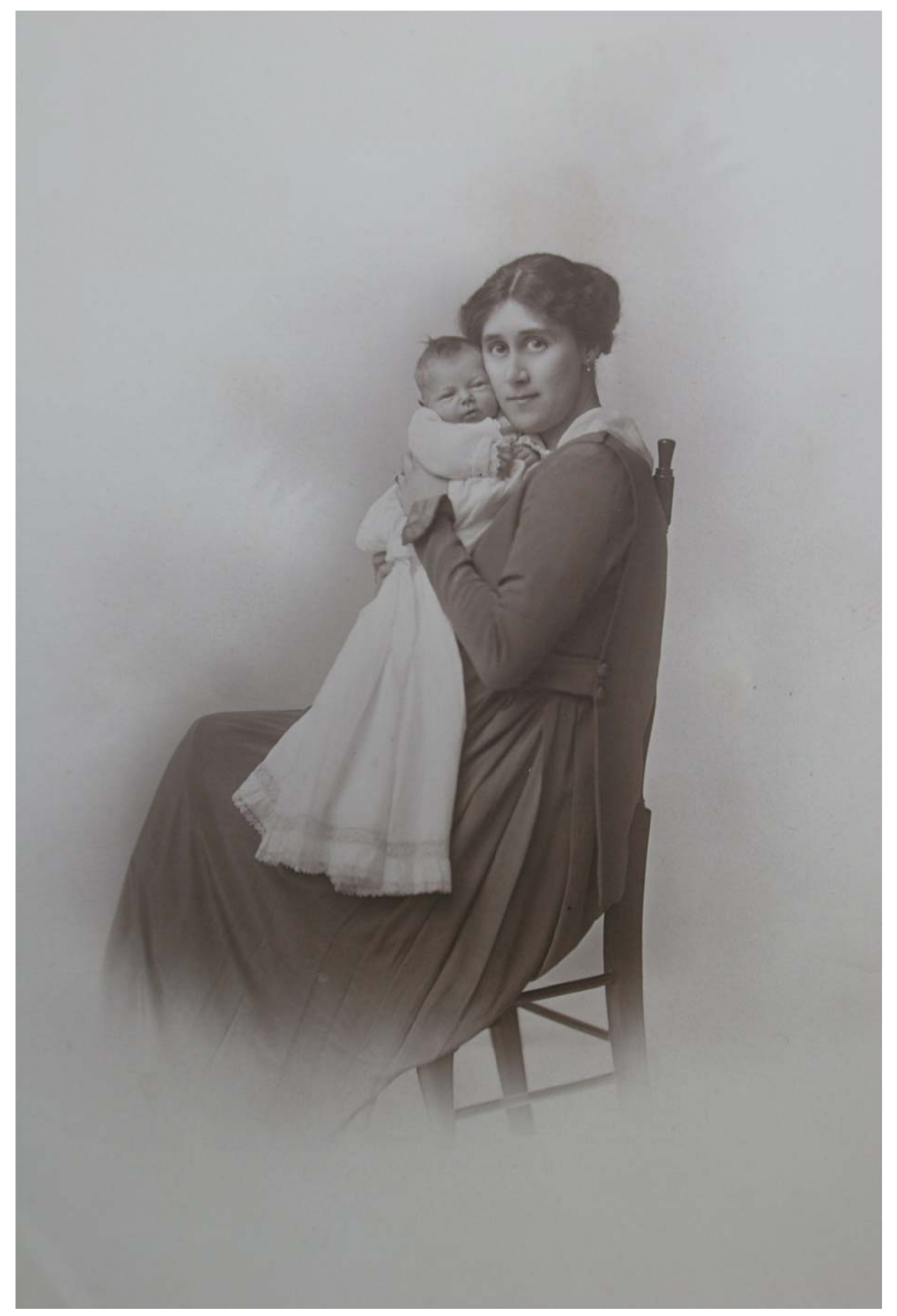

